\title{
Membrane Stability of Red Blood Cells in Diabetic Mice Treated with D-3-O-Methylchiroinositol
}

\author{
Nwaehujor Chinaka $0^{1, *}$, Asuzu Onyeka $V^{2}$, Asuzu Isaac $U^{3}$ \\ ${ }^{1}$ Department of Biochemistry, Faculty of Basic Medical, Sciences, University of Calabar, P.M.B. 1115, Calabar, Nigeria \\ ${ }^{2}$ Department of Animal Production and Health, Faculty of Agriculture, Federal University, Oye, Oye-ekiti, Ekiti State, Nigeria \\ ${ }^{3}$ Department of Veterinary Physiology and Pharmacology, University of Nigeria, Nsukka, Nigeria \\ *Corresponding author: chinaka_n@yahoo.com
}

Received January 17, 2014; Revised January 24, 2014; Accepted February 07, 2014

\begin{abstract}
D-3-O-methylchiroinositol isolated from the stem bark of Piliostigma thonningii was evaluated for membrane stabilizing potentials in red blood cells of alloxan-induced diabetic albino Swiss mice. Blood from diabetic animals treated with different doses of the compound (8, 4, $2 \mathrm{mg} / \mathrm{kg})$ and Glibenclamide $(2 \mathrm{mg} / \mathrm{kg}$ ) were measured for membrane stability at different saline concentrations. The MCF values and their corresponding percentage stabilization were increased in the treatment groups compared to the negative control. The result suggests that D-3-O-methylchiroinositol possesses membrane stabilizing potentials.
\end{abstract}

Keywords: D-3-O-methylchiroinositol, Piliostigma thonningii, osmotic fragility, membrane stabilization, red blood cells, diabetes, albino Swiss mice

Cite This Article: Nwaehujor Chinaka O, Asuzu Onyeka V, and Asuzu Isaac U, "Membrane Stability of Red Blood Cells in Diabetic Mice Treated with D-3-O-Methylchiroinositol.” American Journal of Pharmacological Sciences, vol. 2, no. 1 (2014): 24-26. doi: 10.12691/ajps-2-1-5.

\section{Introduction}

So many physiological defects, imbalances and disease states have been attributed to oxidative stress in living systems. Oxidative damage at cellular level denatures proteins affecting their functions as biological catalysts, carbohydrates by changing their structural conformation and lipids via lipid peroxidation. Cell membranes are made up of mostly lipids which are initial targets for invading micro-organisms, chemical agents, radiation etc. and are often destroyed when attacked. This causes oxidative stress or spontaneous disintegration of the cells and animal as a whole.

The red blood cell (RBC) is considered a whole, generalized and sensitive tissue in a living system and is often employed in the stability studies of a living membrane. The determination of the mean corpuscular fragility (MCF), which is the concentration of saline causing $50 \%$ hemolysis of the erythrocytes, could give a clear idea on how some pharmacological compounds and plant extracts can maintain membrane stability in hypotonic, isotonic and hypertonic solutions. Or destroy it [1].

Red blood cell osmotic fragility or membrane stability can be evaluated using different methods. The traditional osmotic fragility test (OFT) was originally described by Parpart et al [2]. It requires the preparation of series of hypotonic solutions with $\mathrm{NaCl}$ content ranging from $0.1 \%$ to $0.9 \%$, to which a small amount of fresh red blood is added. After centrifugation and absorbance reading at 540 $\mathrm{nm}$, the percent haemolysis is calculated for each solution and plotted against $\mathrm{NaCl}$ concentrations. The resulting osmotic fragility curve is then compared with that obtained with normal controls. The result of the OFT may be expressed as the concentration of $\mathrm{NaCl}$ causing $50 \%$ hemolysis, i.e. the median corpuscular fragility (MCF) [1]. No standards as such are available. A sample from known normal individual is usually collected at the same time as the test sample and run in parallel as a control. The OFT is usually performed on freshly drawn blood (within 2 hours from the collection) but 24 -hour incubation at $37^{\circ} \mathrm{C}$ of the blood sample, has been found to improve the sensitivity of the test since this stress condition results in an increase of osmotic lysis of a greater extent for the abnormal cells respect to the normal ones [3].

D-3-O-methylchiroinositol isolated from the stem bark of Piliostigma thonningii has a structural formula similar to the phosphatidylinositol phosphate, which participates in the insulin signaling pathways that stimulate glucose transport [4]. It has been observed that D-chiroinositol reduced urinary potency with impaired glucose tolerance, insulin resistance and type 2 diabetes mellitus in rhesus monkeys and human subjects [4]. D-chiroinositol also improved glucose tolerance in normal rats and increased gluconeogenesis in the diaphragm.

D-3-O-methylchiroinositol have been proven to possess anti-diabetic [4], anti-helminthic [5] anti-lipidemic [4] and antioxidant activities [4].

$P$. thonningii crude extracts in African folkloric medicine are used in the management of pain, inflammation and edema as well as the haemolytic impairments that accompany these physiological states [6]. 
Thus, we considered it worthwhile to screen D-3-Omethylchiroinositol for membrane stabilizing activities in red blood cells.

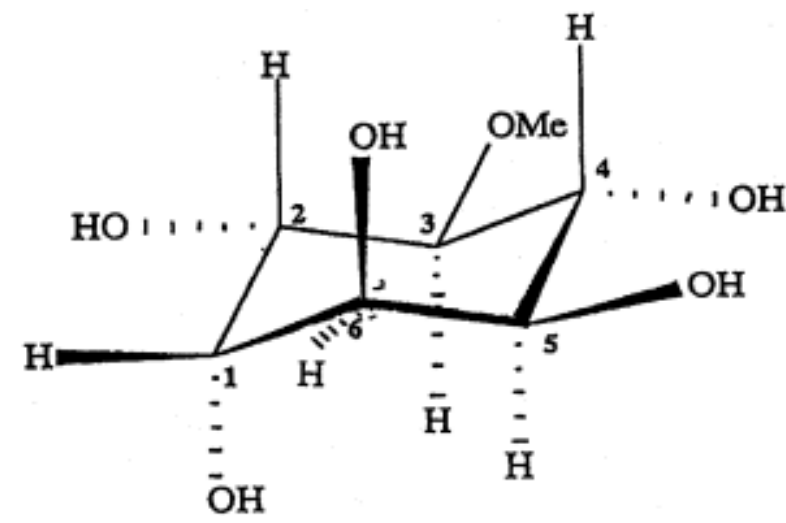

D-3-O-methylchiroinositol

\section{Materials and Methods}

D-3-O-methylchiroinositol was isolated from the stem bark of Piliostigma thonningii as described by Asuzu et al [5]. The pure compound was isolated using column and TLC separation methods, lyophilized and stored in the fridge at $4^{\circ} \mathrm{C}$ until used for the experiments.

\subsection{Animals and Blood Samples}

All experiments with animals were approved by the Ethical Committee of the University of Nigeria, Nsukka.

Male Swiss albino mice (21-28 g) were used. They were housed in standard environmental conditions and fed with standard rodent diet and water ad libitum.

On day 21 post-treatment, blood was collected from 3 diabetic and treated mice in each group $(8,4,2 \mathrm{mg} / \mathrm{kg}$, glibenclamide (2 mg/kg), negative control, and normal) [4] into heparinized tubes. For each blood sample, test tubes were numbered from 1 to 17 . Five $\mathrm{ml}$ of buffered $\mathrm{NaCl}$ ranging from 0.1 to $0.85 \%$ was placed in tubes 1 through 16. Five $\mathrm{ml}$ of distilled water was placed in tube 17.

$0.1 \mathrm{ml}$ of blood was added to each tube and mixed gently and then incubated at $37^{\circ} \mathrm{C}$ for $1 \mathrm{~h}$. the tubes were centrifuged at $2000 \mathrm{rpm}$ for $10 \mathrm{~min}$ to sediment any intact red cells. The haemoglobin content of the supernatant was measured at $540 \mathrm{~nm}$ using a spectrophotometer using the $0.85 \%$-saline tube as a blank and the distilled water tube as the $100 \%$-haemolysis as standard. The highest value of optical density which corresponded to an incubation concentration of $0.1 \% \mathrm{NaCl}$ was taken as $100 \%$ haemolysis.

Percentage lysis was calculated using the formula:

$$
\frac{\text { Abs of test }}{\text { Abs of standard }} \times 100=\% \text { haemolysis }
$$

$\%$ haemolysis was plotted against \% $\mathrm{NaCl}$ concentrations. The mean corpuscular fragility (MCF), which is the concentration of $\mathrm{NaCl}$ producing $50 \%$ lysis was extrapolated from the graphs and recorded. Also, \% stabilization was calculated.

\subsection{Statistical Analysis}

The one way analysis of variance (ANOVA) using unpaired student's t test was used for statistical analysis. The student t-test was applied at 5\% confidence level.

\section{Result}

Table 1. Median Corpuscular Fragility (MCF) values and \% stabilization for diabetic rats treated with D-3-O-methylchiroinositol and glibenclamide

\begin{tabular}{|c|c|c|c|} 
and glibenclamide \\
\hline Treatment group & $\begin{array}{c}\text { Dose } \\
(\mathrm{mg} / \mathrm{kg})\end{array}$ & $\begin{array}{c}\text { MCF }(\% \\
[\mathrm{NaCl}])\end{array}$ & $\begin{array}{c}\% \\
\text { stabilization }\end{array}$ \\
\hline \multirow{2}{*}{$\begin{array}{c}\text { Alloxan + D-3-O- } \\
\text { methylchiroinositol }\end{array}$} & 2 & $0.287 \pm 0.032$ & 28.70 \\
\cline { 2 - 4 } & 4 & $0.333 \pm 0.021$ & 49.33 \\
\cline { 2 - 4 } & 8 & $0.443 \pm 0.014^{*}$ & $98.65^{*}$ \\
\hline Alloxan + Glibenclamide & 2 & $0.421 \pm 0.026^{*}$ & $88.79^{*}$ \\
\hline Alloxan + distilled water & - & $0.223 \pm 0.017$ & 0.00 \\
\hline Control normal & - & $0.438 \pm 0.033^{*}$ & $96.41^{*}$ \\
\hline
\end{tabular}

The MCF values and their corresponding percentage stabilization were increased in the treatment groups as compared to the negative control (marked as *). The highest dose group $(8 \mathrm{mg} / \mathrm{kg}$ ) gave higher \% stabilization than the reference drug (glibenclamide, $2 \mathrm{mg} / \mathrm{kg}$ ) and the normal group. There was also statistical difference between the $8 \mathrm{mg} / \mathrm{kg}$ group, glibenclamide, normal control and the negative control (Table 1).

\section{Discussion}

The osmotic fragility of red blood cells and the body cells in general reflect their ability to take up water without lysis and also withstand hypotonicity [2]. Osmotic fragility is experimentally denoted by MCF values which was statistically higher in $8 \mathrm{mg} / \mathrm{kg}$ and glibenclamide groups, thus, the red blood cells in these groups were able to retain more water volume in a hypotonic solution before 'stretching' of the membrane that progresses to lysis (Table 1). This may explain the prolonged reduction in blood glucose levels observed in these groups [4].

Osmotic fragility tests are based on the measure of red blood cell lysis as a function of osmotic stress [1]. When erythrocytes are placed in hypotonic solutions, they begin to take on water osmotically. This results in swelling of the cell until a critical volume is reached, afterward the membrane at first leaks and then bursts releasing hemoglobin. The susceptibility to osmotic lysis is primarily determined by the surface area to volume ratio of erythrocytes and increased osmotic fragility typically occurs in hereditary spherocytosis. Because of their reduced surface membrane area with respect to the cell volume, spherocytes cannot expand as much as normal discoid erythrocytes and thus, are osmotically more fragile [7]. Increased osmotic fragility is also seen in acquired cases of spherocytosis such as autoimmune hemolytic anemia.

The osmotic fragility tests are mainly useful in the diagnosis of hereditary spherocytosis, beta-thalassemia [3] but they may also be used as a screening test for diabetes, prolonged malfunctions due to high blood pressure and other diabetes-associated diseases in under-resourced countries and conditions where automated blood-cell counters may not be available. This is so since the free radicals (ketones bodies, electrons, hydroxyl groups, gluco-acids) produced as a result of hyperglycaemia in 
diabetes all act to disintegrate cell membranes. D-3-Omethylchiroinositol may be of interest in the treatment of autoimmune hemolytic anemia, beta-thalassemia and hereditary spherocytosis.

\section{Acknowledgement}

Prof. I.U. Asuzu of the University of Nigeria, Nsukka is gratefully acknowledged for allowing the authors to use his laboratory and supplying the compound.

\section{References}

[1] Elekwa I, Monanu MO and Anosike EO (2003) Effects of aqueous extracts of Garcinia kola seeds on membrane stability of HbAA,
HbAS and HbSS human erythrocytes. Global J. of Medical Sciences 2 (2): 97-101.

[2] Parpart AK, Lorenz PB, Parpart ER, Gregg JR and Chase AM (1947) The osmotic resistance (fragility) of human red cells. J. Clin. Invest, 26, 636-638.

[3] Guest GM (1948) Osmometric behaviour of normal and abnormal human erythrocytes. Blood, 3; 541.

[4] Asuzu IU and Nwaehujor CO (2013). The Anti-diabetic, hypolipidemic and anti-oxidant activities of $D-3-O$ methylchiroinositol in alloxan-induced diabetic rats. Hygeia: Journal of Drug and Medicine, 5 (2) 27-33.

[5] Asuzu IU, Gray AI, Waterman PG (1999). The anti-helmintic activity of D-3-O-methylchiroinositol isolated from Piliostigma thonningii stem bark extract. Fitoterapia 70: 77.

[6] Asuzu IU and Onu OU (1994). Antihelmintic activity of the ethanolic extract of Piliostigma thinningii bark in Ascaridia galli infected chickens. Fitoterapia. 65: 291-294.

[7] Ibeh GI, Anosike E. and Ekeke GI. (1992) Effects of age on erythrocyte membrane ATPases in normal and sickle cells. Nig. J. Biochem. 7: 38-46. 